\title{
Play and Exploration in Grade One: Extending the Principles of Early Learning
}

\author{
Kirsten Kobylak and Brenda Kalyn
}

Kirsten Kobylak, M.Ed., is currently a grade 1 teacher for Saskatoon Public Schools. She has previously enjoyed many years as a kindergarten and grade $2 / 3$ teacher, and has found that her passion is in early childhood education. Kirsten believes that children can take charge of their own learning through inquiry and play-based practices. She continues to extend early learning principles into grade 1 by finding ways to merge these ideas with grade 1 curricular outcomes. Kirsten is a wife and a mother to two schoolaged boys.

Brenda Kalyn, PhD is an assistant professor in the Department of Curriculum Studies at the University of Saskatchewan. Her research interests attend to teachers' and students' learning experiences related to curriculum generally and to physical education and health specifically. At the centre of this work is a focus on culturally responsive curriculum that explores holistic models that can be integrated into the life and culture of classrooms to enhance the learning and well-being of children and teachers. Email: brk123@mail.usask.ca

Play, as a pedagogical approach in kindergarten classrooms, is often a common practice and valued within the learning process. As children transition to grade 1, the use of play may not be found within curriculum documents or highlighted as a valuable way to learn. Children in elementary grades should continue to experience learning through play. Examples from this grade 1 class engaged in play throughout a science inquiry cycle demonstrated how learning through play connected with the outcomes of their grade 1 science curriculum. Observations of children engaged in various projects demonstrated motivation for learning, community building through play, and enjoyment in reaching curricular outcomes. Children's work samples, photos, and conversations and the teacher's anecdotal notes provided insights into the benefits of play as a pedagogical approach in grade 1 .

Keywords: play; pedagogy; emergent; holistic; curriculum; instruction teaching, ceased to exist within grade 1 curricular documents. The sudden and apparent devaluing of play became problematic to me. I had observed first hand how much my kindergarten students learned through play activities within our classroom. The children used real tools to build real structures out of real lumber, using screws and nails to facilitate curriculum-based outcomes. They conversed, questioned, interacted, laughed, increased their physical dexterity, stood back and looked at their projects, and decided on new strategies to complete their learning task. As the teacher, I guided their play at times to reach learning outcomes. I saw tremendous value in play as a pedagogical approach.

As a practicing teacher and a graduate student, I was afforded the opportunity in one of my courses to initiate a classroom-based inquiry aimed at understanding a burning desire I had to improve, not only my practice, but also the learning experiences of my students. This practical inquiry was an opportunity to explore the value of play as a pedagogical approach within my grade 1 classroom and observe the effects of play on children and their learning. This article presents an overview of one science unit within my grade 1 classroom, experienced through play-based teaching and learning, and the outcomes of this experience. My goal was to enhance my practice 
through the study of play and contribute these experiences to further the understanding of and possibilities for play as a pedagogical approach beyond kindergarten.

\section{Characteristics and the Value of Play}

Anyone who has played "peek-a-boo" with an infant has experienced one of the first elements of play a child encounters. The child exhibits excitement and expectation through the play. Playful arm and leg movement, quickened breathing patterns, smiling, giggling, anticipated pauses, and interpreting facial expressions of the playing partners are some of the observable characteristics of this play. Each player takes on a role in the play, building on the social, emotional, linguistic, and physical components of this simple act. The child invites the play while the older player guides the play, thereby engaging in a meaningful social exchange. As the child experiences repetition of the actions and the simple patterns of play, the child begins to build on the developmental stages of exploration, trust, feelings of connection, knowing, body language, oral language, and sensorimotor skills (Jones \& Reynolds, 2011; Wood \& Attfield, 2005).

Play builds on the holistic needs of the child through the social, emotional, intellectual, and physical components of growth and development. Play honours diversity and holds no boundaries on age, culture, gender, or choice when children are allowed to explore thoughts and ideas through creative pedagogies such as play. Play invites children to build on what they know and provides them opportunities to put their skills and theories into practice. Play enhances language development, critical thinking, problem solving, and social skills. Children learn to make sense of their world through play, and "a high quality learning environment supports children's learning through play" (Saskatchewan Ministry of Education, 2008, p. 25).

Play is described as voluntary and intrinsically motivated, normally aligned with recreation, pleasurable, regularly associated with children, fun, self-selected, and self-directed; it includes pretending, focuses on the doing (process) and not the product, and requires active involvement (Saskatchewan Online Curriculum, 2010; Wood \& Attfield, 2005). Elizabeth Prescott (in the foreword to Jones \& Reynolds, 2011) states that play is intimately concerned with boundaries and understanding what behaviours might constitute play. She asserts that play requires skills of flexible thinking, shifts in contextual thinking, and the acceptance of new ideas. Play encourages creativity and allows children to make sense of experience.

Elizabeth Wood and Jane Attfield (2005) use descriptors to highlight the processes and skills that children develop through exploration, problem solving, and investigations when playing. These include creating, observing, questioning, manipulating objects and materials, using tools, communicating, developing descriptive language, perceiving and describing, and collaborating, to name a few (p. 213). Exploration often engages children with materials, toys, and props within a learning environment and invites the children into a focused investigation (Smith \& Pellegrini, 2013).

The value of play has been recognized and continues to be researched and taken seriously by the academic community (Wood \& Attfield, 2005). Children make sense of their world through play; they expand their social and cultural understandings, express personal thoughts and feelings, practice flexible and divergent thinking, encounter and solve real problems, learn to consider others' perspectives, negotiate play roles and plans, and develop self-control (Saskatchewan Curriculum, 2010). When children play, they extend their language and literacy skills, and their brain and motor development is enhanced (Jones \& Reynolds, 2011; Skolnick Weisberg, Hirsh-Pasek, \& Michnick Golinkoff, 2013). Play makes space for adults to engage in play with children and guide the process when needed (Canadian Council on Learning, 2006). Play, which requires practice, spans all age groups through to adulthood. The many characteristics of play are valuable and contribute to the ongoing learning processes that children develop over a lifetime. Because of these attributes and effects of play, play should be an integral part of the ways we engage children in learning.

\section{Play as a Pedagogical Approach}

Pedagogy is a discipline that deals with the theory, method, or practice of teaching (Oxford, 2016). Overarching goals within pedagogical practice strive to increase student learning, improve teacher practice, and contribute to professional knowledge. Crucial aspects of pedagogy include organizing and managing classrooms and instructing, assessing, and interacting with students (Shulman, 2003). Teachers have the opportunity to choose pedagogical approaches and apply instructional strategies within their pedagogical practice to enhance learning based on their students' needs and the teacher's professional knowledge and experience (Saskatchewan Ministry of Education, 2008). These decisions are made daily by teachers and reflect the philosophical beliefs that teachers have about teaching and learning. Implementing play, as a pedagogical approach, is one of the practices teachers may choose to enhance student engagement and 
learning outcomes, and there are a variety of approaches to learning through play.

Deena Skolnick Weisberg and her colleagues (2013) discuss the powerful use of play as a pedagogical tool for preschool children, stating that it "allows for teaching rich content in a way that incorporates elements of free play, discovery learning, and traditional pedagogy" (p.105). Teachers make learning through play possible and can be active participants and observers of children who are learning through play (Jones \& Reynolds, 2011). Teachers encourage children's learning through guided play and may act as co-players, inquirers who ask probing questions, and listeners who wait for the right time to open new possibilities for children to explore through their play experiences.

Guided play is situated between free play and direct instruction and involves the teacher as the director in this child-centered process. Children remain active collaborators in their learning. As a result, they are more likely to be engaged in the learning and find greater meaning in the outcomes due to their direct participation, while guided play takes advantage of children's natural response tendencies to successfully scaffold their learning (Skolnick Weisberg et al., 2013; Wood \& Attfield, 2005).

As children play, they often engage in different roles or behaviours. Children's play may appear functional, constructive, dramatic, and/ or game like. Onlooker behaviour demonstrated by the child may make it appear as though the child is reluctant to participate in existing play due to shyness or nervousness. Conversely, children "use onlooker behavior to help them make choices, to decide which activity to select, or to ascertain the most effective strategy for gaining entrance into an already established play episode" (Van Hoorn, Monighan Nourot, Scales, \& Rodriguez Alward, 2003, p. 37). Solitary play, in which children may be seen playing alone, without taking initiative to join any existing play opportunities, may also be mistaken for a type of social inhibition. For both onlooker behaviour and solitary play, the teacher plays an important role that involves understanding that children need time for privacy as well as guidance toward activities that interest them (Van Hoorn et al., 2003).

Group play, where children play together, is important for achieving a collaborative process or outcome. Within the definition of group play, parallel play occurs when children share materials and play close to their peers but do not cooperate or coordinate their play (Van Hoorn et al., 2003, p.38). Associative play is similar, but serves as a bridge between parallel play and group play. In associative play, management and sharing of materials and space occur, but each child works on their own. Ultimately, cooperative play, defined as "sophisticated efforts to negotiate joint play themes and constructions with peers" (p. 39) and characterized "by children stepping in and out of their play to establish roles and events" (p. 39), would provide the best results for a classroom inquiry project.

The skilful teacher is one who makes play possible through a rich play environment and helps children learn through play. The teacher acts as observer, stage manager, mediator, challenger, player, planner, and scribe, to name a few of the many roles that teachers engage in while children play (Jones \& Reynolds, 2011). As children represent their learning through revisiting, revising, and re-creating knowledge and experiences, teachers also represent their pedagogical practices in meaningful ways to enhance children's learning through play by selecting appropriate strategies to guide learning. Creating purposeful learning environments that account for students' current skill levels while also encouraging growth for their maturing thought processes is a result of considerable planning by experienced educators adept at understanding the importance of play and development. As children play and learn to master age-related tasks during kindergarten and beyond, they move toward more rational, logical thinking. Play can be an integral part of this growth and development as more sophisticated ways to play and learn emerge.

Charles Pascal (2009), special advisor on early learning for the province of Ontario states:

Play is serious business for the development of young learners. This is such an important understanding. A deliberate and effective play-based approach supports young children's cognitive development. When well designed, such an approach taps into children's individual interests, draws out their emerging capacities, and responds to their sense of inquiry and exploration of the world around them. It generates highly motivated children enjoying an environment where the learning outcomes of a curriculum are more likely to be achieved. (p. 25)

Play begins very early on in life, and when children play, learning occurs. The more opportunities for young learners to engage in play, the greater the possibilities are for learning through play. 


\section{Play as a Lifetime Learning Experience}

Play is often considered a central learning approach within pre-kindergarten and kindergarten classrooms. When children make the transition to grade 1, the perception of formal schooling begins, and a common trend is to find children sitting in desks or at tables for extended periods of time. Play appears to be devalued as a learning approach beyond kindergarten. Some critics contend that what teachers should do is teach and argue that without direct instruction and teachers talking, there is no learning in school (Jones \& Reynolds, 2011). However, this perspective reduces children to passive learners (Skolnick Weisberg et al., 2013).

The paradigm shift that occurs between kindergarten and grade 1 is unrealistic and abrupt. If playing is pleasurable, engaging, and creates feelings of joy and passion in learning, it should become an integral and accepted practice beyond kindergarten. Play should not be relegated to a "thing of the past," recess, or strictly leisure activity. Wood and Attfield (2005) assert that "if playing and growing are synonymous with life itself, then lifelong playing can be seen as an important aspect of lifelong learning" (p. 13).

Providing students time to play provides opportunities for children to explore and create deeper levels of thinking through building literacy skills, manipulating objects, building relationships, exploring real and imaginary perspectives, and having a choice in their learning (Saskatchewan Ministry of Education, 2008). Grade 1 curricula have different outcomes and expectations than kindergarten; however, the value of play does not need to change. The grade 1 curriculum in Saskatchewan does not mention the word play; however, it does mention the use of inquiry-based learning, which could serve as an opportunity to implement play as a pedagogical approach. Inquiry invites children to ask, search, investigate, manipulate, and engage in learning through interactive, playful ways.

Older children should be engaged in higher levels of play than younger children, and this requires a belief that play is valuable to children above the kindergarten level and has many benefits across the curriculum (Stone, 1996, p. 104). Frost, Wortham, and Reifel (2001) state:

The shift of focus from the make-believe play of the preschooler to the growing frequency of playing organized games of the school-aged child should transition gradually with continual attention to providing play materials and equipment for cognitive, social, and language development through the primary grades. (p. 434)

Play is a natural activity for children. It assists them in problem solving and stretching their imagination, shaping their identity, and fostering self-expression (Jones \& Reynolds, 2011). However, implementing play as a pedagogical approach in grade 1 would involve challenging the norms and traditional expectations of formal learning. How play is conceptualized in relation to learning and teaching determines how teachers implement play within more advanced learning opportunities beyond kindergarten.

\section{Learning Through Play: A Classroom Inquiry}

Inquiring into one's practice as a teacher requires grappling with innovations, ideas of tension, and challenges that move us into new directions (Sizer \& Sizer, 1999). Caring about our practice as teachers and believing in the needs of our students draws us to the heart of our teaching (Noddings, 1995). As a teacher of young children, looking for creative and critical ways to improve student learning is forefront in my practice. Embarking on the inquiry described in this article within my classroom required a great deal of reflection and commitment to play as a pedagogical approach. My goals were to support student learning through play and enhance my own professional development as a teacher who struggled with the tensions and lack of play-based learning as I transitioned from teaching kindergarten into a grade 1 classroom.

The purpose of this classroom inquiry was to extend play into a grade 1 classroom to explore children's learning experiences and observe how this pedagogical approach could affect curricular outcomes in one science unit. Figure 1 represents the central questions of the inquiry. 


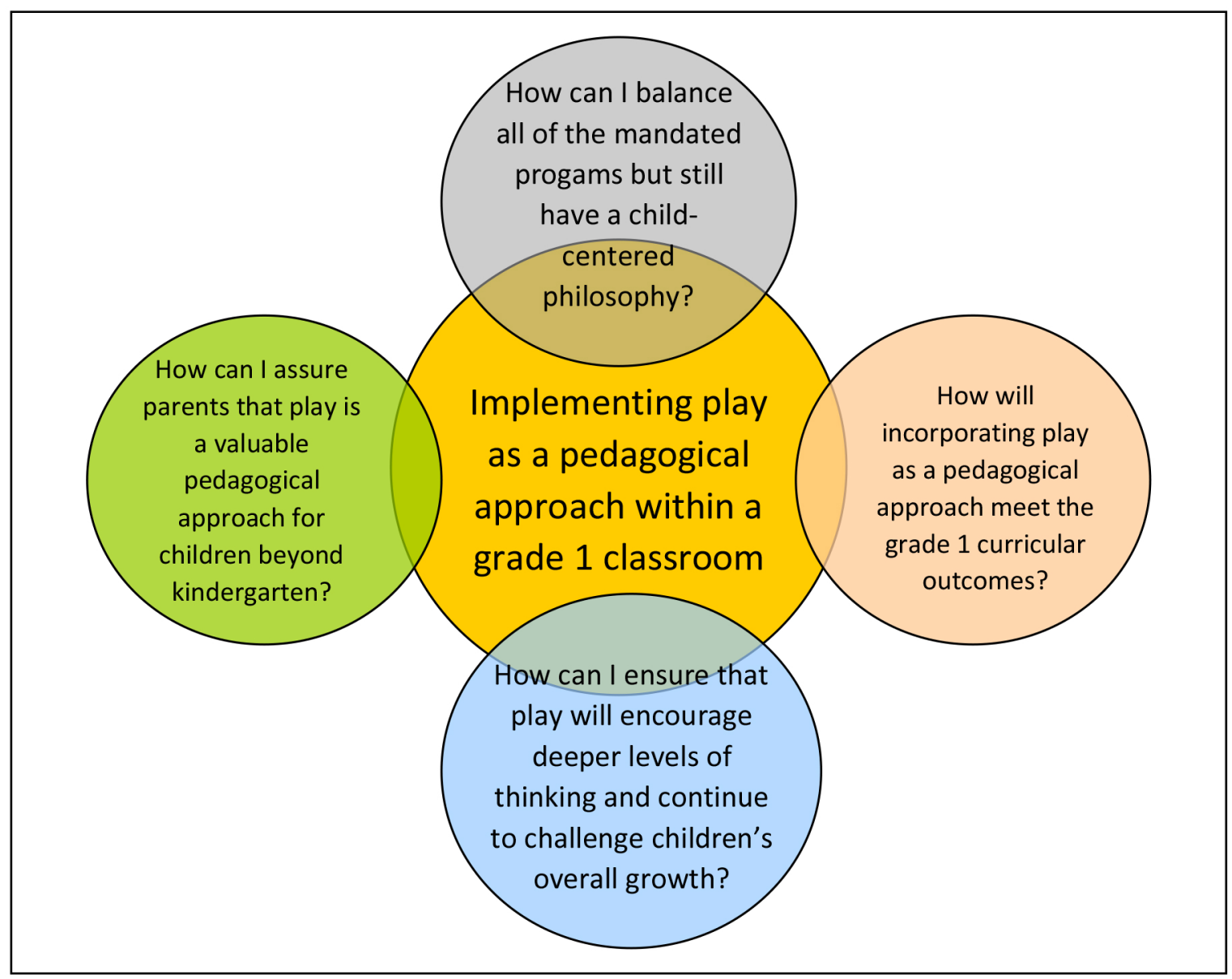

Through a well-planned series of observations, collection of artifacts, listening to and observing my students, and documenting personal reflections, I came to a better understanding of the value of play within my students' learning experiences.

Over a two-month period within one science inquiry cycle, play was implemented as a pedagogical approach to foster learning and exploration of ideas, concepts, and questions. The characteristics of play complement an inquiry approach to learning. Specifically, inquiry is described by the Saskatchewan Ministry of Education (2011) as an active, lifelong learning strategy that generates knowledge and values the child as learner. Additionally, Just Science Now (2017), an online professional learning resource for teachers, supports play within science inquiry:

Inquiry means that students are handling science; they are manipulating it, working it into new shapes and formats, integrating it into every corner of their world, and playing with it in unknown ways. Inquiry implies that students are in control of an important part of their own learning where they can manipulate ideas to increase understanding. As students learn to think through the designs and developments of their own inquiry, they also develop a sense of self-responsibility that transcends all subject areas. (para. 1)

To inform my inquiry and better understand the children's perspectives, the children were invited to respond to the following questions:

- What does playing mean?

- What does work mean?

- What do you need in order to play?

- Can you learn at the same time as you play?

- How do you know you are playing? 
A common theme that emerged from the children was that playing is about having fun, exploring, and discovering new things. The children determined that playing and learning could happen at the same time, and they specified that anything the teacher told them to do was considered work. Jane Perlmutter and Louise Burrell (1995) suggest that in a classroom where teachers effectively provide a balance between child-chosen and teacher-assigned activities, the "lines between work and play become blurred" (p. 14). Children understand that learning and play go together. They explore and inquire, either internally or externally, about what an object, situation, or tool, can do, and when they decide, they can apply their ideas through play.

To ensure that play and exploration happen successfully, children have to be in control of their ideas. In our classroom inquiry, the children played an important part in developing a direction for their learning. The entire inquiry process was then based on that information, and these grade 1 students became the leaders in their own learning process.

\section{The Emergent Curriculum: A Learning Sample}

This inquiry began as a result of recognizing and responding to the children's interests. The children were presented with a variety of monthly calendars and challenged to pick out interesting things they noticed on the calendars. They began to generate several questions of interest regarding the little circles on selected calendar dates. Upon learning that those circles represented the phases of the moon, the children wanted to learn more about how the moon benefits our world. The Saskatchewan Ministry of Education (2011) includes a section regarding earth and space in its curriculum that provided an opportunity to merge the children's interests with curricular outcomes. Following the children's lead, the researcher, Brenda Kalyn, and I developed an essential question: "Why is it important to explore new worlds?"

A teacher's expertise at crafting one important question from the many questions children generate is important and provides direction for emergent curriculum (Copple, 2014; Fraser, 2012; Wien, 2014). Developing this question was the beginning of our inquiry into the ways I, as teacher, would guide the children into deeper learning by using play as a pedagogical approach. It was important to meet curricular outcomes and follow the children's interests by providing "strong purposeful curriculum activities embedded with rich learning" (Wien, 2014, p. 88). As we journeyed through our inquiry, we experienced the emergence of new ideas and positive learning outcomes through play. As the classroom teacher, I was directly immersed in the classroom experiences and documented student learning through play by journalling anecdotal notes of classroom activities and observations. Note taking in the natural setting can be a major source of information for the teacher and may include methods, field observations, theoretical notes or personal notes (Hubbard \& Power, 2003).

A class grid containing children's photos as part of the anecdotal notes proved a quick way to keep track of children's quotes during learning. I acted as scribe (Jones \& Reynolds, 2011) using the grid to jot down notes while observing and listening to the children at play. This information was used to learn the children's interests and to encourage expansion on topics of interest.

Due to the spontaneity of play and exploration, social interaction, a changing learning environment, and an inquiry approach, careful documentation and reflection were needed to continuously provide opportunities for the children to extend their learning and stay on task. Conversations, photographs, constructions, writing sample charts, and a teacher's journal were used to ensure that the learning remained relevant and to extend learning opportunities through play (Jones \& Reynolds, 2011). Curricular connections were made during daily analysis of field notes, and a printout of the curricular outcomes was available to write notes onto while observing the children playing and learning. This type of documentation delineates the indicators of student learning to ensure that curricular outcomes are met. The indicators mentioned in the curriculum were "not a checklist or prioritized list of instructional activities or prescribed assessment items" (Saskatchewan Ministry of Education, 2010a, p. 12). If the outcomes are understood, "teachers may develop their own indicators that are responsive to their students' interests, lives, and prior learning" (p. 12). There is room for differentiation and movement toward higher-level thinking as children lead their learning by creating, testing, inventing, planning, and producing a finished product and the desired outcome. This flexibility in responding to and guiding student inquiries allows for play and exploration to be valuable teaching approach in consecutive grades. These careful observations are an important piece of the teacher's work and provide the autonomy as professionals to guide the learning processes using strategies that are responsive to our students' needs and our philosophical ideologies.

The collection of children's samples (Figure 2) was important for organizing and displaying their learning. The use of a portfolio helped to organize the collected samples and both the children and I were involved in the process of collecting work samples, as it was important for the children to monitor their own progress (Copple, 2014). 


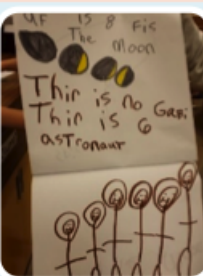

Non-fiction books were created based on research the students conducted

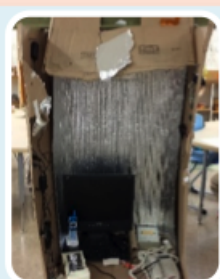

We made crystals in the research center of our ISS (Intemational Space Station) to dramatize research in space as a way of advancing medicine

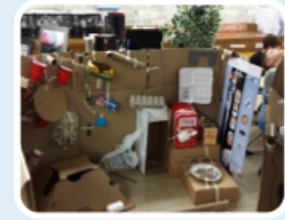

\section{One module} of the ISS representing the kitchen. Dramatizing an astronaut's life in space.

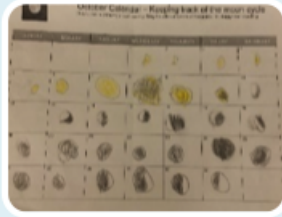

The students kept a moon calendar to observe how and why the moon changes.

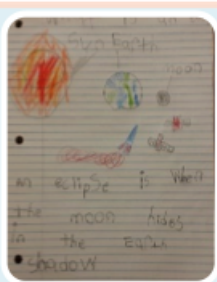

Features and aspects of literacy were practiced as the students wrote sentences and paragraphs

Figure 2. A collection of children's learning samples.

The principles of early learning in the Play and Exploration Early Learning Guide (Saskatchewan Ministry of Education, 2008) were a priority throughout the inquiry process, which honoured the holistic, competent nature of children's learning and the importance of building positive learning relationships through a dynamic learning environment. Piaget's (1962, as cited in Stone, 1995, pp. 46-47) four levels of cognitive play were implemented as a way to ensure the children were developing cognitively. At the end of each school day, the activities the children experienced were placed into one of those four areas of play. This provided a visual record into what the children had completed and what they needed to work on. Figure 3 shows how field notes were used to collect information to view what was being done (both curricular based and socially based) in relation to Piaget's four levels of cognitive play.

\section{Why is it important}

Functional -using senses to feel bumpy textures representing moon surface, finding moon rocks outside, making moon dough, using flour as moon dust, working with clay to roll into moon shapes and make craters with various objects

\section{to explore new worlds? \\ - Piaget's cognitive levels of play}

Constructive - collecting research and building a representation of the International Space Station ISS), recording phases of the moon for one month, growing crystals in the research center of their space station, making their own non-fiction moon books, creating a list of space vocabulary, drawing pictures representing the moon phases, composing a song about a theory of how the moon was created

Dramatic - dramatizing the life of an astronaut, performing experiments, creating and acting out an astronaut exercise schedule, role playing positions such as commander or mission specialist, dramatizing meteors hitting the moon to create craters

Games with Rules - astronaut and alien tag, problem solving regarding roles in a group, lists and rules about behavior in the space station and the shuttle, taking turns piloting the ship

Figure 3. Field note observations of play.

Once the children had completed construction of their space station, other types of play became evident. They immediately became involved in social play as they used their materials to create many dramatic scenes representing the jobs of astronauts. They engaged in 
positive social behaviour such as cooperation as they built tools to fix the station and demonstrated reciprocity through taking turns in exchanging materials. As the children used materials to experiment with what worked and what didn't work, constructive play combined with group play and consequently enhanced their social interactions. These interactions within the play setting displayed a growing maturity as the children shared an interest and practiced social rules with the authentic, common goal of learning about the space station.

Reflection on daily observations allowed me to choose specific areas in which direct instruction was necessary. Building a space station required instructions on how to use the computers to research information, pick out the main ideas, and take jot notes. Specific instructions on how to write informational paragraphs were also provided, and the children used this knowledge to write culminating paragraphs about their learning. Analyzing student writing demonstrated that outcomes from the language arts curriculum were being met through their writing, shared stories, and short informational texts. The explicit writing instructions that the children created were in response to their desire to share their information with classmates and others.

Pedagogical documentation (Fraser, 2012; Kocher \& Pacini-Ketchabaw, 2014) is a process where teachers gather important information as evidence of children's learning. The evidence showcases ideas and theories generated by children and provides the teacher opportunities to reflect and analyze what is being learned. Through the analysis, the teacher is better able to follow and support the children's interests and facilitate new and important directions to satisfy their curiosity, answer their questions, and open new pathways for further investigations as the curriculum emerges, and this relies heavily on the teacher's observations (Jones \& Reynolds, 2011). The teacher gains a deeper understanding of the meaning in the explorations.

The class picture grid (Figure 4) with individualized anecdotal notes revealed the interests that each child had toward the topic of space inquiry and what each child provided to the learning, often spontaneously. Children were bringing artifacts from home that included purchased or student-made books and pictures about the moon or an astronaut's life. They also began to ask more questions and chose to do research as they explored information on computers and in books. Disassembling old computers was of extreme interest to some children, who carefully chose pieces to place into the research centre of their space station. The actual construction of the space station revealed different interests as the children engaged in authentic dialogue while planning, constructing, and then dramatizing within their creation. Holistic learning took place as the children moved through their inquiry focus. When conditions are optimal for learning, children will explore and exhibit advanced and sophisticated play using their own energy. For example, I observed my grade 1 students raising a long box and problem solving ways to attach the Canada-arm to the space station. We discussed how difficult it would be to build something while they were floating in space. The difficulties were something we researched, and then we applied the new knowledge through active play.

Analysis of children's work was ongoing, demonstrating the benefits of play and exploration and ensuring that the curricular outcomes were achieved. Reflection on field notes taken during the process showed the following outcomes from the Saskatchewan Grade One Science Curriculum (Saskatchewan Ministry of Education, 2011) that were met.

(Objects and Materials 1.1) - Investigate observable characteristics and uses of natural and constructed objects and materials in their environment.

(Objects and Materials 1.2) - Examine methods of altering and combining materials to create objects that meet studentand/or teacher-specified criteria.

(Daily and Seasonal Changes 1.1) - Compare and represent daily and seasonal changes of natural phenomena through observing, measuring, sequencing, and recording (pp. 29-30,33).

The documentation and display of the children's learning provided a visual representation of our progress and guided further learning (see Figure 4 below). The children were involved in the processes of planning, implementing, and selecting items to display. They were engaged and motivated and wanted to participate as active learners. Because the children were highly engaged in purposeful, authentic tasks that created a positive atmosphere for learning, there were few behavioural problems. 


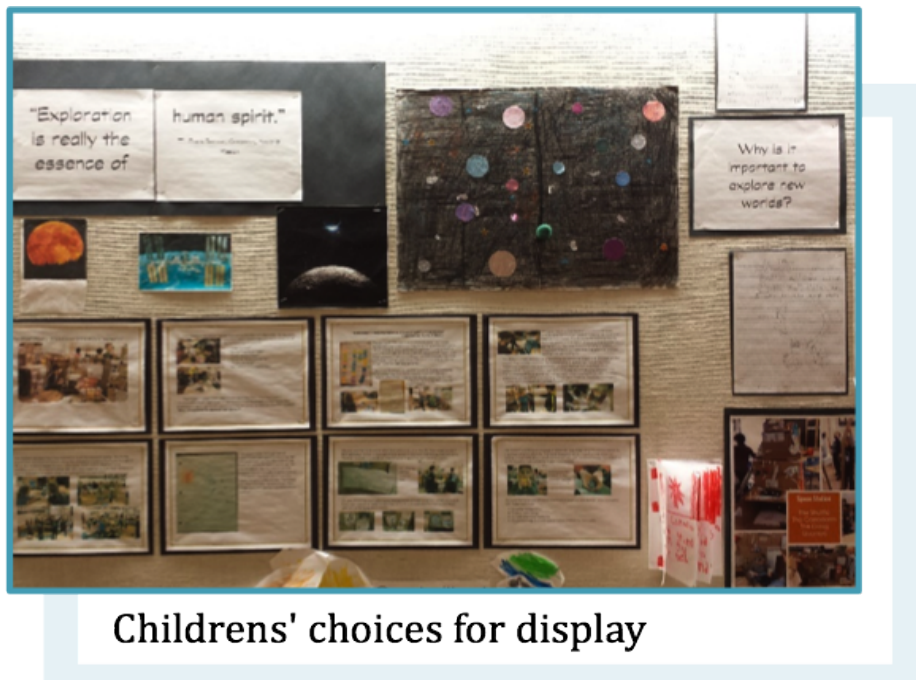

\section{The students were proud of their work and thoughtfully chose pieces for display.}

Figure 4. Children's choices for display.

When teachers and students become co-constructors of learning, a respectful, equal, and interactive relationship emerges (Fraser, 2012). Children are accepted as competent learners and reciprocity becomes a part of the learning practices. Children's ideas are deemed important (Copple, 2012) and their contributions are expected and respected. Learning is exciting, unpredictable, reciprocal, and emergent, and both teachers and their students are fulfilled through the experience of learning through play.

\section{Assessment Through Play}

Susan Fraser (2012) discusses the relationship between assessment and documentation as tools to measure learning. Assessment and evaluation have typically been used to measure abilities and outcomes from a scientific paradigm that focus on factual responses and a rather narrow view of learning. Documentation, on the other hand, uses a wider lens to capture the richness and depth of children's learning. Documentation also takes into account multiple intelligences and respects the role of the learner and different paths of learning.

When implementing play as a pedagogical approach in this classroom inquiry, documenting the children's learning through observations, interactions, conversations, questioning, artifacts, and listening was key to assessment. Carefully observing how children interacted with materials and resources offered insight into what materials and other supports might be needed in the future to guide their learning. I observed the emergence and intersection of several cross-curricular outcomes, including writing, language development, cooperative behaviours, mathematical conversations, designing and manipulating objects into representations of their learning, descriptions and explanations how their ideas resulted in their projects, artistic representations, and demonstrations of their learning in relation to our inquiry question specifically related to science.

While observing children interacting with each other and the space station, I was available to show them how to research their questions through the internet, provide books for further inquiry, collect samples of their writings and drawings, and take pictures for display and further discussion. A holistic approach to assessment was needed, because play as a pedagogical approach values all aspects of the learning, including the social, emotional, intellectual, and physical components. Matching the type of assessment to the pedagogical approach provided consistency and a fair perspective on student learning. Play allowed for children's interests to guide the learning. It is important that teacher observations are properly documented in a variety of ways to help the children produce projects that accurately capture their interests and abilities.

Fraser (2012) stresses that listening to children can go deeper through analyzing and reflecting on what children are saying in order to uncover and better understand the meaning within the communication. Listening carefully challenges the teacher to learn deeper contextual meanings in student learning and is important within a reciprocal learning experience. This purposeful listening approach affirms the children's presence and respects what they bring to their learning through play. Listening and probing by the teacher encourages children to further express their ideas, helps to shape their understandings, encourages more questions, and provides the teacher with information 
needed to enhance learning and interpret learning outcomes the children are experiencing. Here, we see listening as dialogical. As Lev Vygotsky (1930-1935/1978, as cited in Singer, Michnick Golinkoff, \& Hirsh-Pasek, 2006) stated, "cooperative dialogues between children and more knowledgeable members of their society are essential for children to acquire uniquely human, higher cognitive processes" (p. 76). These reciprocal conversations are important aspects of the process to promote higher-level thinking.

Teachers have an important role when including play as a pedagogical approach, assessing learning, and guiding students to meet curricular outcomes. The grade 1 students in this class enhanced their understanding of the functions of the International Space Station by asking questions, conducting research, and then acting it out. My role was to listen to their questions, provide resources to support and encourage high-quality play, and structure an environment that fostered their interests by providing books, instruction on computers, materials, and outside help from the parents and the community. Guiding the play toward meeting curricular objectives requires active participation of the teacher.

\section{Outcomes of the Inquiry}

Throughout this inquiry process, the children defined work as anything the teacher told them to do. Play to the children meant having fun, exploring, and discovering new things while learning and taking charge of this process. The children took command of their space station project in many ways, all of which required research that the children did primarily on their own. Some made food for the kitchen, which involved learning about how and what astronauts ate. Others decided to pilot the shuttle and grappled with the concepts of north and south directions. Tools were needed to fix any malfunctions, so the children created blowtorches and first aid kits while discovering that the shuttle crew needed doctors and engineers. As the teacher, of course, I needed to be actively present and guide the children by providing them with information and materials necessary to achieve their goals.

The activities that took place during the inquiry showed that children's play was natural, developmental, and contributed to curricular outcomes. Play was central throughout the inquiry and was led by the ideas and the interests of the children. Recognizing play as a valid pedagogical approach benefitted student learning and supported the children in their holistic growth. The children created new knowledge and applied processes to problems and questions. They engaged physically in their learning and enhanced their socialemotional development through interactions, relationships, and the emotional contexts of learning. The children were part of the planning and implementing of the inquiry, which created greater awareness of their learning processes. The more that I was able to provide time for the children to practice and explore ideas while providing materials to enhance their learning, the easier it was for the children to guide their inquiries. A continuous search for knowledge and, in turn, representation of learning led the children to understand that there had to be some explicit learning involved in order to find answers to their questions. Because play was embraced by the children and supported and guided by the teacher, learning was inevitable.

I was repeatedly amazed by the work that the children were producing through diagrams, pictures, and writing, and their documentation told great stories of their learning journey. It was also a learning journey for me as I gained just as much knowledge together with them about our topic as I provided guidance, materials, and opportunities for extending learning through play. Positivity toward school was shown on a daily basis because the children were excited and proud to show their parents the space station that was unceasingly under construction.

The spontaneity, curiosity, and questions of the children brought the project to life and allowed it to grow from a topic in science to a cross-curricular project. Hirsh-Pasek and Golinkoff (2003, as cited in Singer et al., 2006) suggest that "when children are in environments where learning is occurring in a meaningful context, where they have choices and where they are encouraged to follow their interests, learning takes place best" (p. 9). The children in my class showed leadership and took responsibility toward their learning that exceeded expectations. Learning through play honoured the children's abilities to demonstrate their enthusiasm and love of learning. I hope they continue to learn through play throughout their lives.

\section{Extended Outcomes}

Within our moon inquiry, it was easy to address multiple curricular outcomes. For example, including new vocabulary and opportunities for writing lessons became a necessary part of our research inquiry and presentation of our learning artifacts. Mathematics was included through a space counting book as part of our final product. Children interacted and engaged in role playing, told stories, became physically involved in the creation of their projects, had fun and cooperated with each other, and so on. 
Parental engagement was an important component within our moon inquiry as we increased the bond between home and school. Families regularly contributed to our play and exploration in many ways, from donating large boxes of old electronics to helping to arrange possible guest speakers. Books and pictures were spontaneously brought from home by children to share. Some of these books were purchased and some were written and illustrated by the children. The sharing of these books led to a study of the characteristics of nonfiction text that motivated children to create additional books of their own. Creation stories and art were also brought for sharing that led us to investigate First Nations creation stories of the moon.

Families also helped their children at home by observing the moon patterns with them every night and developing more questions about the size, shape, and colour of the moon. Regular communication through documentation was implemented to keep both the children and their families informed on the curricular outcomes that were being achieved. Families visited our space station on a daily basis and often mentioned how much their child was learning about the moon and space exploration. The inquiry proved to form strong, positive learning relationships between school and home, an important value that stays true to the early learning philosophy (McMillan \& Schumacher, 2010).

Learning through play proved to be exciting for my students, and they played a significant part in directing their learning. As they explored thoughts and ideas through creative pedagogies, they were actively building their language skills as they communicated wonderings, questions, and ideas. This inquiry created space for respecting the diversity of children's ideas, their imaginative approaches, their personal input, and the creative ways they used to solve problems and make sense of their questions. I was able to observe them bustling around the classroom and engaging in exciting activities, determine when instruction or materials were necessary to help with skills and ideas, and celebrate their "findings." This inquiry project has underscored for me that children are active and capable learners. It is quite wonderful to see the ways that children's interests can be connected to the curriculum in meaningful ways.

During this inquiry, the children were affirmed in their work and a sense of industry was apparent. They believed in their work and their play, and the success they felt was inspiring. To be affirmed in one's learning feeds the heart of the learner and is empowering. This empowerment provides the learner with trust in their learning and a belief in their learning capacity.

\section{Concluding Thoughts}

The positive results of this inquiry have motivated me to continue to implement play as a pedagogical approach in my grade $1 \mathrm{classroom}$. Having been with the children for a full school year, I have seen them continue to grow and thrive. They have engaged in higher levels of play and critical thinking, months after our moon inquiry. Using play as a pedagogical approach and implementing play as a regular part of our routines has supported children in becoming comfortable and more confident in asking questions regarding topics that are of interest to them and then engaging in research to find answers. The enthusiasm the children have toward learning is the driving force behind my continuation of using play as a pedagogical approach in grade 1 .

Teachers are a major part of the play process in the classroom context and can become filled with excitement when they see their students motivated and engaged. According to the Saskatchewan Ministry of Education (2008), teachers are encouraged to apply various strategies within their practice to increase student engagement, reach a variety of learners, and inspire creativity. These practices could also serve to enhance the teacher's experience and maintain a passion for teaching. Time should be invested in providing professional development opportunities for teachers that demonstrate the theories, practices, and potential of play-based education. Challenging one's practice and implementing new strategies are tasks that many teachers embrace if they are provided with the essential tools to begin applying new ideas. Everyone loves to play in one form or another. Placing more play in our classrooms will benefit teachers, children, and their learning communities.

\section{References}

Canadian Council on Learning. (2006). Let the children play: Nature's answer to early learning. Retrieved from: http://galileo.org/ earlylearning/articles/let-the-children-play-hewes.pdf

Copple, C. (2014). Response. In C. A. Wien, The power of emergent curriculum: Stories from early childhood settings (pp. 88-89). Washington, DC: National Association for the Education of Young Children. 
Fraser, S. (2012). Authentic childhood: Experiencing Reggio Emilia in the classroom (3 ${ }^{\text {rd }}$ ed.). Toronto, ON: Nelson Education.

Frost, J. L., Wortham, S. C., \& Reifel, S. (2001). Play and child development. Upper Saddle River, NJ: Merrill/Prentice Hall.

Hubbard, R., \& Power, B. M. (2003). The art of classroom inquiry (rev. ed.). Portsmouth, NH: Heinemann.

Jones, E., \& Reynolds, G. (2011). The play's the thing. New York, NY: Teachers College Press.

Just Science Now. (2017). What is inquiry? Retrieved from: http://www.justsciencenow.com/inquiry/index.htm

Kocher, L., \& Pacini-Ketchabaw, V. (2014). Response. In C. Wien, The power of emergent curriculum: Stories from early childhood settings (pp. 61-63). Washington, DC: National Association for the Education of Young Children.

McMillan, J., \& Schumacher, S. (2010). Research in education: Evidence-based inquiry (7 $7^{\text {th }}$ ed.). Upper Saddle River, NJ: Pearson Education.

Noddings, N. (1995). Teaching themes of care. The Phi Delta Kappan, 76(9), 675-679.

Oxford University Press. (2016). Pedagogy. Retrieved from: https://en.oxforddictionaries.com/definition/pedagogy

Pascal, C. (2009). With our best future in mind: Implementing early learning in Ontario. Retrieved from: http://ywcacanada.ca/data/ research_docs/00000001.pdf

Perlmutter, J., \& Burrell, L. (1995). Learning through "play" as well as "work" in the primary grades. Young Children, 50(5), 14-21.

Saskatchewan Ministry of Education. (2008). Play and exploration: Early learning program guide. Retrieved from: http://www.education. gov.sk.ca

Saskatchewan Ministry of Education. (2010a). Renewed curricula: Understanding outcomes. Retrieved from: http://edonline.sk.ca/ bbcswebdav/library/curricula/English/Renewed_Curricula.pdf

Saskatchewan Ministry of Education. (2010b). Saskatchewan curriculum language arts grade 1. Retrieved from: http://www.education. gov.sk.ca

Saskatchewan Ministry of Education. (2010c). Saskatchewan online curriculum: The importance of play. Retrieved from: http://www. curriculum.gov.sk.ca

Saskatchewan Ministry of Education. (2011). Saskatchewan curriculum. Retrieved from: https://www.edonline.sk.ca/bbcswebdav/ library/curricula/English/Science/Science_1_2011.pdf

Shulman, L. S. (2003). Knowledge and teaching: Foundations of the new reform. In A. Ornstein, L. Behar-Horenstein, \& E. Pajak (Eds.), Contemporary issues in curriculum ( ${ }^{\text {rd }}$ ed.; pp. 109-127). Boston, MA: Pearson Education.

Singer, D., Hirsh-Pasek, K., \& Michnick Golinkoff, R. (2006). Play = learning: How play motivates and enhances children's cognitive and social-emotional growth. New York, NY: Oxford University Press.

Sizer, T., \& Sizer, F. (1999). Grappling. The Phi Delta Kappan, 81(3), 184-190.

Skolnick Weisberg, D., Hirsh-Pasek, K., \& Michnick Golinkoff, R. (2013). Guided play: Where curricular goals meet a playful pedagogy. Mind, Brain, and Education, 7(2), 104-112.

Smith, P. K., \& Pellegrini, A. (2013). Learning through play: Encyclopedia on early childhood development (rev. ed.). London, England: Goldsmiths, University of London. 
Stone, S. J. (1995). Wanted: Advocates for play in the primary grades. Young Children, September, 45-54.

Stone, S. J. (1996). Integrating play into the curriculum. Childhood Education, Winter 95/96, 104-107.

Van Hoorn, J., Monighan Nourot, P., Scales, B., \& Rodriguez Alward, K. (2003). Play at the center of the curriculum (3 ${ }^{\text {rd }}$ ed.). Columbus, $\mathrm{OH}$ : Merrill Prentice Hall.

Wien, C. A. (2014). The power of emergent curriculum: Stories from early childhood settings. Washington, DC: National Association for the Education of Young Children.

Wood, E., \& Attfield, J. (2005). Play, learning and the early childhood curriculum (2 $2^{\text {nd }}$ ed.). Thousand Oaks, CA: SAGE. 